\title{
ECTROS-ID: SEBUAH APLIKASI SELULER UNTUK MANAJEMEN DAYA
}

\author{
Eko Setyaji Marwono', Cintya Rahel2, Ignatius Andika Dwi Nugroho \\ Information Systems Department, \\ School of Information Systems \\ ${ }^{1}$ eko.marwono@binus.ac.id, ${ }^{2}$ cintya.rahel@binus.ac.id, ${ }^{3}$ ignatius.nugroho@binus.ac.id \\ Bina Nusantara University \\ Jakarta, Indonesia 11480 \\ Harco Leslie Hendric Spits Warnars \\ Computer Science Department, \\ BINUS Graduate Program - Doctor of Computer Science \\ spits.hendric@binus.ac.id \\ Bina Nusantara University \\ Jakarta, Indonesia 11480
}

\begin{abstract}
The paper aims to manage and control using power. This paper's theme of saving electrical energy, designed using IP addresses. A mobile application called EctroS-ID (Electronic Smart) as an electrical power controller. The purpose of the design is to connect with such things as air conditioning, lighting, television, and others so that they can operate the latest technology such as smartphones, tablets and more. This paper is also expected to ease the burden of regarding electricity usage. This application is also equipped with push and pull services.
\end{abstract}

Keywords : EctroS-ID (Electronic Smart ID), sistem manajemen energi (EMS), SCC (komunitas terhubung pintar), manajemen infrastruktur pusat data (DCIM).

\begin{abstract}
Abstrak
Makalah ini bertujuan untuk mengelola dan mengendalikan penggunaan daya. Tema makalah ini tentang penghematan energi listrik, yang dirancang menggunakan alamat IP. Aplikasi mobile bernama EctroS-ID (Electronic Smart) sebagai pengontrol daya listrik. Tujuan dari desain ini adalah untuk terhubung dengan hal-hal seperti AC, pencahayaan, televisi, dan lainnya sehingga mereka dapat mengoperasikan teknologi terbaru seperti smartphone, tablet dan banyak lagi. Makalah ini juga diharapkan dapat meringankan beban penggunaan listrik. Aplikasi ini juga dilengkapi dengan layanan push dan pull.
\end{abstract}

Kata kunci : EctroS-ID (Electronic Smart ID), sistem manajemen energi (EMS), SCC (komunitas terhubung pintar), manajemen infrastruktur pusat data (DCIM).

\section{PENDAHULUAN}

Kemajuan teknologi saat ini sedang mengalami perkembangan yang sangat cepat dan mengarah ke banyak penemuan di bidang teknologi. Berbasis cloud computing (internet) untuk menghubungkan koneksi antara perangkat lunak dan perangkat keras melalui saluran komunikasi internet yang bisa kita sebut (cloud computing). Melalui cloud computing, smartphone juga dapat digunakan untuk mengontrol perangkat elektronik yang berada di ruangan baik rumah, kantor, sekolah, dan lainnya. kita dapat memantau dari lokasi mana pun. 
Energi listrik sangat dibutuhkan dan selalu diletakkan berdampingan dengan aktivitas manusia di seluruh dunia. Sama seperti di Indonesia, banyak konsumsi listrik dengan cepat terkuras oleh kenyataan bahwa jumlah orang yang lahir setiap tahun meningkat. Penggunaan energi listrik tidak dapat dihindari, seperti penggunaan televisi, AC, pengisian daya smartphone, lampu dalam ruangan, dan banyak lagi.

Manajemen daya mengoptimalkan kontrol arus listrik pada peralatan elektronik, yang dapat memengaruhi keandalan, kinerja, biaya, dan waktu tunggu (pasar-ke-pasar). Penting untuk IoT atau perangkat seluler, didalam sejumlah besar aplikasi, seperti mobil, tertanam, atau ruang. Menentukan domain daya adalah langkah pertama yang harus dipertimbangkan sebelum menerapkan jaringan IP tertentu atau strategi distribusi energi. Peningkatan biaya dan permintaan energi sudah banyak organisasi untuk menemukan cara cerdas untuk memantau, mengendalikan, dan menghemat energi yang digunakan atau dibutuhkan. Sistem manajemen energi pintar (EMS) dapat berkontribusi untuk mengurangi biaya dan pada saat yang sama, memenuhi permintaan energi. Teknologi Emerging Internet of Things (IoT) dan Big Data dapat digunakan untuk mengelola konsumsi energi dengan lebih baik di sektor perumahan, komersial, dan industri. Dokumen ini menyajikan Sistem Manajemen Energi (EMS) untuk rumah pintar. Dalam sistem ini, setiap perangkat rumah adalah modul akuisisi data yang terhubung yang merupakan objek IoT dengan alamat IP unik yang menghasilkan perangkat jaringan nirkabel besar. Dengan menggunakan teknologi IoT, konsumsi energi real-time dapat dikumpulkan dan dianalisis secara efisien, yang mengarah pada peningkatan kesadaran dan evaluasi konsumsi energi dari proses produksi. Kami percaya bahwa Internet of Things (IoT) memiliki potensi jaringan yang terhubung di mana-mana dan sensor pintar untuk komunitas koneksi pintar, dan analisis data yang luas memiliki potensi untuk mentransfer IoT ke kontrol waktu-nyata yang diinginkan untuk SCC. [9], [16]

Sistem manajemen energi rumah diharapkan lebih efisien untuk mengurangi konsumsi energi di area rumah atau ruangan. Kami menganggap ruangan menjadi mudah dikendalikan oleh remote control dengan IP sehingga peralatan rumah tangga yang menggunakan aplikasi listrik dapat dikontrol. Kode IP dan edukasi sinyal kendali jarak jauh IP dari peralatan rumah tangga yang terhubung ke outlet (dihidupkan atau dimatikan).

Sistem manajemen energi eksternal dirancang untuk memecahkan masalah peralatan dan mengurangi waktu henti. Dengan Remote Power Management dalam aplikasi dan alamat IP statis, manajer TI, keamanan dan telekomunikasi dapat memulai ulang perangkat menggunakan browser web dan kata sandi standar. Perangkat yang dikunci dapat diatur ulang dari PC desktop, laptop, ponsel cerdas, atau tablet.

Manajemen energi pusat data adalah proses luas yang memungkinkan pengelolaan, pengukuran, dan pemantauan pembangkit listrik, konsumsi, dan optimalisasi fasilitas pusat data. Ini adalah bagian dari proses manajemen infrastruktur pusat data (DCIM) yang bertujuan untuk memberikan kontrol administratif atas alat dan proses energi listrik di pusat data.

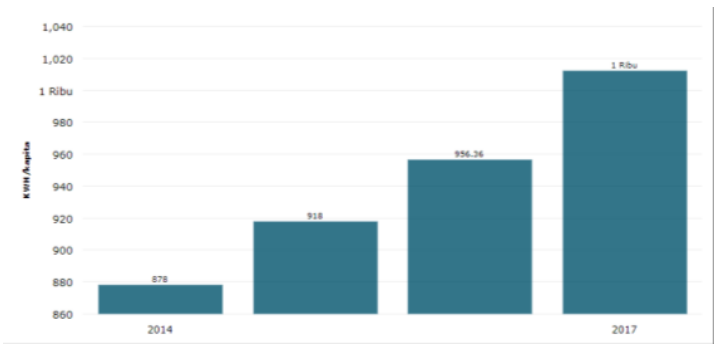

Gambar. 1. Diagram data konsumsi listrik Indonesia per kapita 2014 - 2018.

Data dari hasil diagram pada Gambar 1 adalah peningkatan konsumsi listrik Indonesia per kapita (2014-2018). Data horizontal menggambarkan data dari tahun ke tahun. Data vertikal menunjukkan jumlah KWH / Kapita yang dicapai per tahun. Diketahui bahwa pada 2014 ada 878 KWH / kapita, pada 2015 ada 918 KWH / kapita, pada 2016 ada 956,36 KWH / kapita, dan pada 2107 1ribu KWH / kapita tercatat. [3]

Perkiraan konsumsi tarif listrik, misalnya:

1. Enam lampu menyala dari 17:00 Dengan asumsi, sampai pukul 5:00 pagi, total daya adalah 6 × 30 watt $\times 12$ jam $=2.160$ watt.

2. 2 unit AC yang dihidupkan diperkirakan dari jam 9:00 pagi sampai jam 5:00 pagi. Jadi total daya penggunaan $\mathrm{AC}$ dalam sehari adalah $2 \mathrm{x}$ $750 \times 8$ jam $=12$ ribu watt.

3. TV LED yang menyala hanya tiga jam sehari. Konsumsi daya harian adalah $55 \times 3$ jam = 165 watt.

4. Setrika listrik digunakan selama 1 jam; maka konsumsi daya adalah $350 \times 1$ jam $=350$ watt. 
5. Kulkas selama 24 jam, konsumsi daya adalah $280 \times 24$ jam $=6.720$ watt.

6. Mesin cuci digunakan selama 1 jam sehari. Maka daya adalah $350 \times 1 \mathrm{jam}=350$ watt.

Menghitung lampu + AC + TV LED + setrika + lemari es + mesin cuci $=2.160 \mathrm{watt}+12.000$ watt +165 watt +350 watt +6.720 watt +350 watt $=$ 21.745 watt per hari. Perhitungan tarif listrik menggunakan unit Kwh, atau Kilowatt per jam atau jam. Untuk mendapatkan unit Kwh, maka 21.745 watt: $1000=21.745 \mathrm{kWh} .21 .745 \mathrm{kWh} x$ Rp 1.467.26 (grup listrik) = Rp 31.905.56, Jika biaya listrik Anda sehari dalam jumlah itu, tagihan listrik Anda dalam sebulan kurang lebih: Rp. 31.905,56 x 30 hari = Rp. 957.166.8. Namun, itu semua tidak pasti karena penggunaan listrik rumit untuk mengukur secara manual, dan perkiraannya belum, tentu akurat. Karena itu, kita dapat mengantisipasi hal-hal yang tidak diinginkan, seperti lupa mematikan elektronik rumah tangga, yang terus-menerus menghabiskan energi listrik dan menyebabkan biaya tagihan listrik yang tinggi. [1] konsumsi energi di Indonesia.

Ini adalah penggunaan energi listrik yang jelas di berbagai bidang, termasuk di industri, rumah tangga, perusahaan, transportasi, dan sektor lainnya.

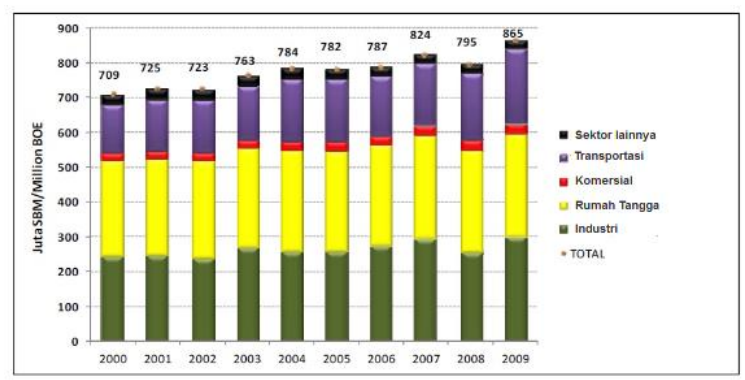

Gambar 2. Contoh sektor konsumsi energi.

Seperti ditunjukkan pada Gambar 2 di atas, diketahui bahwa sektor listrik adalah yang terbesar di sektor industri, rumah tangga, dan transportasi. Selain itu, dapat dipastikan bahwa seiring peningkatan waktu penggunaan listrik dari tahun ke tahun, ini merupakan peningkatan yang signifikan, salah satu perspektif diambil dari tahun 2000 hingga 2009 [7]. Kita dapat mulai melakukan gerakan penghematan listrik dari rumah tangga, atau semua sektor kamar, yang dapat dibantu oleh jaringan internet teknologi modern saat ini.

\section{TINJUAN PUSTAKA DAN TEORI}

\section{A. Pustaka}

Pada bagian ini diuraikan teori-teori yang berkaitan erat dengan topik bahasan penelitian. dimana peneliti sebelumnya harus membaca referensi tulisan ilmiah dengan tema serupa dari jurnal ilmiah internasional atau nasional yang dapat dilihat di http://scholar.google.com, atau jika memang tidak ada yang seperti akan dibuat oleh peneliti, maka peneliti (penulis) dapat menggunakan referensi buku terbaru. Peneliti harus dapat menjelaskan tentang penelitian yang pernah dibuat sebelumnya dari referensi yang peneliti baca, apa yang sudah pernah dibahas dan apa yang belum dibahas dan dapat dikembangkan pada penelitian saat ini. Apa yang membedakan penelitian peneliti saat ini dengan penelitian dengan tema sejenis yang ada sebelumnya. Tuliskan resume peneliti tentang penelitian sebelumnya tersebut di tinjauan pustaka. Minimal pembahasan dari 5 jurnal ilmiah (internasional atau nasional).

\section{B. TCP / IP DAN LAYANAN TARIK DAN PUSH}

Seiring waktu, teknologi tumbuh dan semakin memunculkan ide-ide luar biasa dalam meluncurkan teknologi terbaru. Jaringan komputer (client-server) adalah tempat untuk berinteraksi dan bertukar data antara komputer yang berbeda. Penggunaan alamat IP, dalam hal ini, adalah perilaku server dan klien. Seperti halnya aktivitas internet, penggunaan alamat IP menunjukkan lokasi komputer host berada di smartphone, tablet, dan sebagian. Berdasarkan alamat IP-nya, kombinasi angka dalam digit individu dan dipisahkan oleh titik-titik dan tentunya setiap perangkat memiliki IP yang berbeda. [4]

Di sini kita memiliki gagasan untuk menghubungkan elektronik berbasis listrik ke alamat IP yang dapat menghemat listrik di masa depan dengan menetapkan alamat IP dari masing-masing identitas elektronik dan dapat dikendalikan berdasarkan pada model clientserver sehingga jarak tidak menjadi masalah saat mengendalikan benda. Kontrol dapat menggunakan teknologi paling canggih dan terkini, seperti ponsel cerdas, tablet, iPad, dan sejenisnya, didukung oleh koneksi internet.

TCP (Transmission Control Protocol) dan IP (Internet Protocol) adalah simbol dari nama yang dimiliki satu sama lain dalam komunikasi data. TCP / IP menyatukan perangkat keras komputer dengan berbagai merek dan mengintegrasikan 
berbagai merek perangkat lunak sehingga komputer dan komputer lain menggunakan berbagai perangkat keras dan perangkat lunak komputer dapat mengkomunikasikan data melalui internet. TCP / IP dapat bekerja melalui Ethernet, saluran dial-up dan secara virtual melalui berbagai transmisi data media fisik. Ini dapat digunakan sebagai alamat publik sehingga setiap perangkat yang menggunakan TCP / IP memiliki alamat unik pada jaringan komputer lokal atau jaringan komputer global. [6]

\section{Format IP:}

Formatnya tidak sama untuk setiap alamat IP (berbeda). Beberapa alamat digunakan untuk mengidentifikasi jaringan, dan nomor digunakan untuk mengidentifikasi host, alamat IP masingmasing elektronik harus berbeda, ada ketentuan bahwa alamat IP menunjukkan identitasnya pada setiap IP yang diinstal secara elektronik. Ada dua jenis IP berdasarkan kegigihan IP yang terkait dengan perangkat komputer:

1. Alamat IP dinamis (terlepas dari apakah alamat IP publik atau alamat IP pribadi), alamat IP yang diperoleh oleh perangkat komputer berubah setiap kali perangkat komputer dihidupkan ulang, IP Dinamis tidak memerlukan pengaturan manual, karena IP secara otomatis ditetapkan oleh router (server DHCP) untuk perangkat yang terhubung ke komputer yang terhubung ke jaringan.

2. Alamat IP statis, IP yang dipasang secara manual atau IP yang ditetapkan secara khusus untuk perangkat komputer (router, tablet, smartphone, perangkat pintar, dll.), Sehingga ketika perangkat dihidupkan ulang, IP tidak berubah. Mungkin aplikasi ini dapat menggunakan IP statis karena hanya ditujukan untuk pemilik / pengguna.

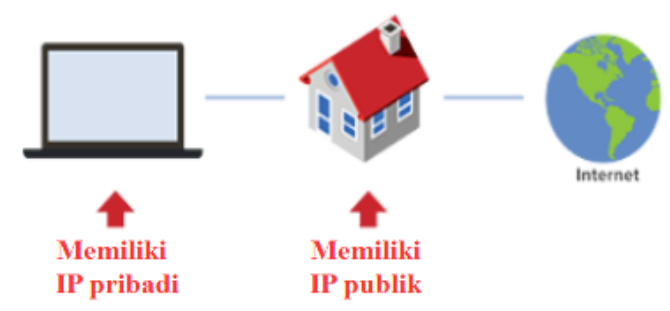

Gambar. 3. Koneksi jaringan

Gambar.3 di atas menunjukkan bahwa setiap perangkat memiliki IP pribadi dan dapat diinstal pada perangkat elektronik rumah tangga seperti televisi, AC, lampu, dan elektronik lainnya.

\section{IP yang Terlarang:}

Dilarang atau diblokir berdasarkan alamat IP yang paling umum digunakan oleh pengguna atau berpotensi mengancam pengguna sistem. Sistem pemblokiran IP diterapkan secara efektif jika pengguna menggunakan IP Static karena IP statis diperbaiki dan tidak dapat diubah IP dan tidak akan mendapatkan IP baru yang berbeda dari IP dinamis yang dapat memperoleh IP baru bahkan setelah diblokir. Aplikasi ini akan menggunakan Banned IP ketika pengguna asing mengakses perangkat pemilik untuk menghindari hal-hal yang tidak diinginkan; lebih aman untuk diakses.

\section{METODOLOGI PENELITIAN}

Dari penelitian sebelumnya, kami menemukan perangkat yang disebut Electronic Creative (Electrive) yang dapat dihubungkan 3, 4, dan maksimal 12 saluran perangkat elektronik. Misalnya, terhubung dengan lampu ruangan, AC, kulkas, televisi, dan lainnya. Namun, kami tidak mengerti apa yang dipasang di elektronik. Penelitian sebelumnya yang kami temukan hampir sama dengan ide aplikasi smartphone kami, yaitu aplikasi IP di setiap elektronik yang akan terhubung ke smartphone. IP - Internet pengguna. [12]

Ada alat yang disebut Remote Control System. Sistem kendali jarak jauh yang dibuat untuk mengendalikan elektronik menggunakan sirkuit Driver Relay. Penelitian sebelumnya merancang relay driver ini sebagai sakelar hidup / mati yang dapat dikontrol dari peralatan elektronik yang akan dikontrol oleh pengguna. Pengguna hanya perlu membuka browser web dan mengakses IP Server yang terhubung ke peralatan elektronik sehingga mereka dapat mengontrol Driver relay sebagai sakelar hidup / mati. [24]

Penelitian sebelumnya yang kami temukan berdasarkan pada jaringan IP pada remote control dan terhubung ke elektronik, perangkat lunak ini secara fisik terhubung ke jaringan Internet untuk aplikasi web tertanam dan PLC antara host tertanam dan driver perangkat. Protokol (HTTP) didefinisikan dan dibuat untuk berkomunikasi antara host yang disematkan dan driver perangkat yang dibangun sehingga saling terhubung. [10].

Sistem Kontrol Perangkat Elektronik Berbasis Rumah Tangga dan Arduino menjadikan Arduino komponen utama yang mendukung komponen elektroniknya. Relai sirkuit Arduino 
digunakan sama dengan sakelar yang dapat menghubungkan atau memutuskan arus listrik ke elektronik yang terhubung. Sistem ini dirancang berdasarkan program mikrokontroler Arduino, di mana ada sinyal dari mikrokontroler Arduino yang akan dikirim ke masing-masing elektronik. [10] Perangkat Keras Arduino ini didukung oleh prosesor Atmel AVR dan bahasa pemrograman dalam perangkat lunak. [25], [14]

Kabin terintegrasi dengan sistem rumah pintar. Kabin berfungsi sebagai pengontrol perangkat elektronik seperti remote AC atau remote TV. Kabin juga dapat dikendalikan dari jarak jauh di luar ruangan. Kabin tidak dijelaskan dengan jelas dalam fitur yang digunakan [19]. Dynamic power management (DPM) adalah alat yang efektif menggunakan node sensor yang dapat mengontrol apa pun yang dibutuhkan atau tidak diperlukan [23]. Berfokus pada perancangan sistem manajemen energi berbasis IoT berdasarkan infrastruktur komputasi ujung, banyak penelitian yang memanfaatkan IoT (Internet of Things) dalam mengelola sesuatu seperti elektronik, banyak ide kreatif yang muncul untuk menciptakan sesuatu yang baru yang bermanfaat. [22]

Dua konsep dapat digunakan untuk mewujudkan rumah pintar, yaitu Internet of Things (IoT) dan Network Control Systems (NCS). IoT adalah penghubung antara internet dan juga yang terhubung dengan elektronik dan NCS sebagai kestabilan sinyal yang dapat melakukan kegiatan ini (mengendalikan jaringan antara IoT dan elektronik) [20]. Layanan server pusat data sangat penting untuk digunakan untuk mendukung sebagian besar layanan Internet, seperti hosting Web dan layanan e-commerce. Layanan ini dapat mengakomodasi manajemen daya dan energi untuk sistem server untuk memfasilitasi kontrol sistem elektronik. [21]

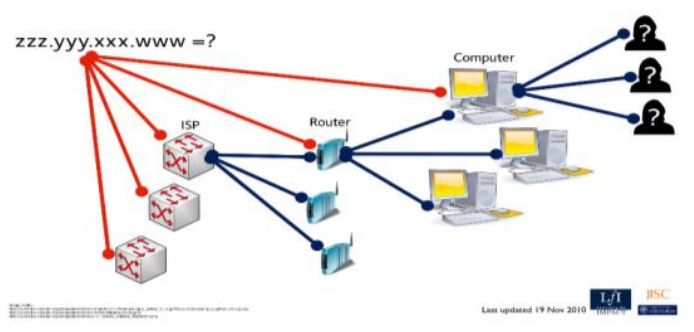

Gambar 4. Koneksi IP ke pengguna
Seperti yang ditunjukkan pada Gambar 4, zzz.yyy.xxx.www =? Misalnya, IP yang terhubung ke penyedia internet (penyedia internet) adalah penyedia layanan internet dan layanan terkait lainnya. IP yang terkait dengan ISP yang terhubung ke router dapat menghubungkan perangkat komputer / ponsel / tablet yang akan diproses hingga pengguna akhir [5]. Aplikasi ini juga dilengkapi dengan layanan push dan pull. Layanan tarik memberikan informasi yang diminta langsung dari pengguna serta pengoperasian perangkat. Untuk layanan tarik, pemisahan lebih lanjut dapat dilakukan menjadi layanan fungsional, seperti menghidupkan / mematikan dengan hanya menekan tombol on / off pada perangkat, atau layanan informasi, seperti mencari informasi tentang penggunaan listrik. Misalnya, seperti pada gambar 9 (a), Anda dapat menekan atau mematikan perangkat.

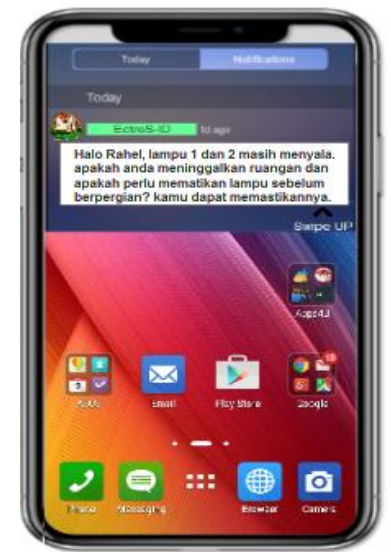

Gambar.5. Pemberitahuan layanan Informasi Sistem Ectros-ID

Berdasarkan gambar 5 di atas, tipe ini adalah pengingat notifikasi. Berdasarkan input pengguna dan data dari sumber eksternal, aplikasi mengirimkan pengingat, sehingga pengguna tidak kehilangan peluang penting atau hal-hal yang perlu mereka lakukan. Misalnya, munculnya peringatan untuk mematikan listrik. Aplikasi ini dapat mengirim notifikasi sederhana kepada pengguna ketika mereka memasuki atau meninggalkan lokasi. Pemberitahuan geolokasi memungkinkan Anda membuat batas virtual untuk area aplikasi tertentu dan dapat mengirim pemberitahuan push ke semua pengguna di area tersebut. Fitur ini dapat membantu pengguna dalam pemberitahuan tentang listrik. [27] 


\section{HASIL DAN PEMBAHASAN}

Dalam aplikasi smartphone yang kami usulkan, kami menerapkan fungsi alamat IP untuk menggunakan elektronik yang didasarkan pada energi listrik. Gabungkan atau sambungkan melalui internet dengan jaringan komputer (client-server); keuntungannya adalah penghematan listrik, yang menghasilkan efek positif dari penggunaan yang tepat dan hemat energi, sehingga memudahkan pengguna untuk mengetahui perkembangan konsumsi listrik setiap hari, dan dengan mudah memantau konsumsi listrik dalam tujuan tertentu.

Usulan kami dalam use case, seperti yang terlihat pada gambar 6 menjelaskan hubungan aktor dengan sistem.

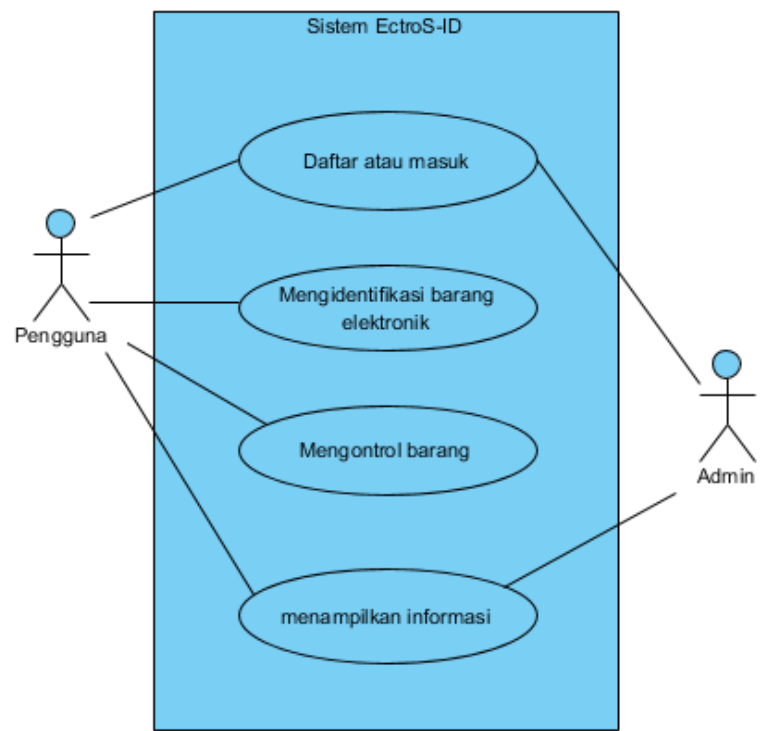

Gambar. 6. Contoh dari UseCase EctroS-ID

Aktivitas dalam diagram use case EctroS-ID adalah:

1. Pendaftaran atau masuk. Langkah pertama, pengguna harus menjadi akun masuk dalam aplikasi ini atau pendaftaran jika pengguna tidak memiliki akun. Admin akan terdaftar dan menyimpan akun pengguna dalam database. Gambar 7 menunjukkan menu masuk (a) dan daftar (b). Pendaftar harus memasukkan nama, jenis kelamin, nomor ponsel, alamat email, dan kata sandi. Setelah akun dibuat, pengguna harus masuk dengan memasukkan alamat email dan kata sandi.

2. Identifikasi barang elektronik. Setelah login, pengguna harus mengidentifikasi perangkat elektronik yang digunakan, user Interface (UI) pada gambar 8 (a) menunjukkan halaman setelah Masuk. Di mana di halaman ini ada dua opsi di mana pengguna dapat mengidentifikasi perangkat mereka atau mendapatkan informasi. Admin akan menyimpan perangkat yang telah diidentifikasi. Gambar 8 (b) menunjukkan halaman untuk mengidentifikasi perangkat mereka; pengguna dapat memilih perangkat apa yang ingin diidentifikasi. Gambar 10 menunjukkan pengaturan perangkat lain dengan alamat IP; pengguna juga bisa mendapatkan perangkat lain yang diinginkan dengan memasukkan alamat IP.

3. Mengontrol barang. Pengguna dapat mengontrol perangkat elektronik yang telah diidentifikasi. Gambar 9 (b) menunjukkan halaman perangkat kontrol di mana pengguna dapat memilih perangkat mana yang harus dikontrol, diaktifkan dari jarak jauh, atau mematikan perangkat di mana pun pengguna menginginkannya.

4. Lihat informasinya. Pengguna aktivitas terakhir dapat melihat informasi tentang perangkat sehingga mereka dapat mengelola penggunaannya dengan lebih baik. Gambar 9 (a) menunjukkan halaman perangkat informasi tempat pengguna dapat melihat informasi perangkat yang digunakan.

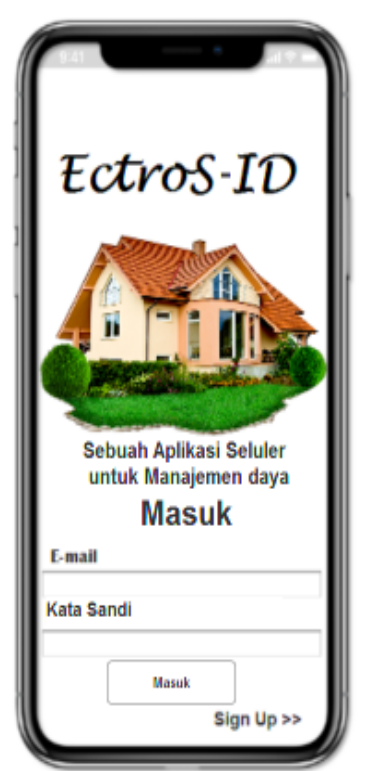

(a)

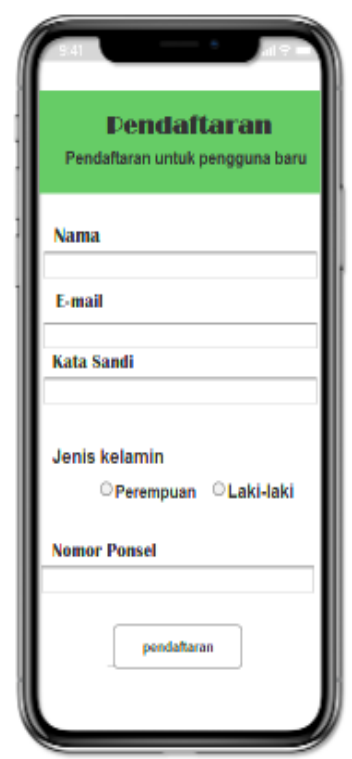

(b)
Gambar. 7. (a) Halaman Masuk, (b) Halaman Pendaftaran 


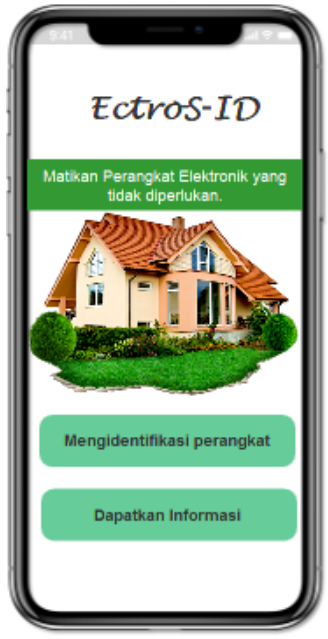

(a)

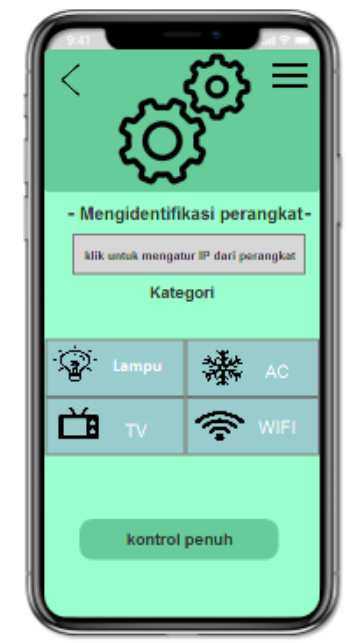

(b)
Gambar. 8. (a) Setelah Halaman Masuk, (b)

Halaman Identifikasi perangkat

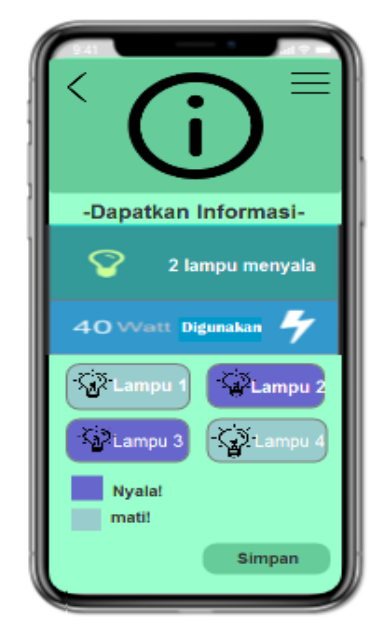

(a)

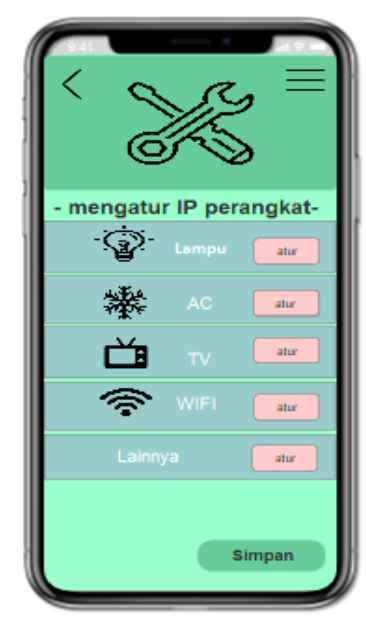

(b)
Gambar.9. (a) halaman Informasi Perangkat, (b) Halaman Perangkat Kontroler

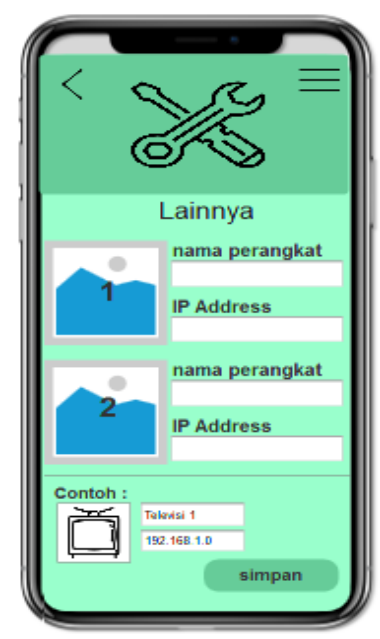

Gambar.10. Pengaturan IP perangkat lainnya

\section{KESIMPULAN DAN SARAN}

Kesimpulan yang dapat ditarik untuk makalah ini adalah penghematan listrik yang dapat dilakukan secara efisien dan efektif. Kita dapat langsung mengendalikan elektronik di kamar rumah, kantor, industri, dan sekolah tanpa harus khawatir tentang jarak dan pemikiran seperti lupa, ceroboh, dan karena alasan lain. Misalnya, jika seseorang bepergian pada suatu hari, ia membutuhkan kepastian tentang elektronik yang mereka gunakan, apakah elektronik yang mereka gunakan keadaanya hidup atau mati. Mereka dapat menggunakan teknologi telepon pintar yang terhubung ke alamat IP dari properti elektronik rumah / kamar sehingga dapat dikelola dari jarak jauh untuk menghasilkan efektivitas dan efisiensi dalam keadaan tertentu, dan pengguna juga dapat memperoleh semua informasi tentang listrik yang mereka gunakan.

\section{Daftar Pustaka:}

[1] Akbar, A. (2018). Begini Lho Cara Menghitung Tarif Listrik yang Benar. [Online]. Available: https://www.moneysmart.id.

[2] Ddkealia. (2014). Konsep Identitas komputer, IP Address dan Sharing Jaringan. [Online]. Available: https://ladygodiva99.wordpress.com.

[3] ESDM, K. (2018). Inilah Konsumsi Listrik Nasional. [Online]. Available: https://databoks.katadata.co.id on 2 July 2019.

[4] Hermawan. (2019). Pengertian IP Address Beserta Fungsi dan Kelas IP Address pada Jaringan Komputer. [Online]. Available: https://www.nesabamedia.com.

[5] Marshall, C. (2010). What's in an IP address?. [Online]. Available: https://blogs.it.ox.ac.uk.

[6] Ordinary, A. (2016). Mengenal Perbedaan IP Publik dan IP Private Serta Jenisnya. [Online]. Available: https://www.tembolok.id.

[7] Sutrisna, K. F. (2012). Kondisi dan Permasalahan Energi Listrik di Indonesia. [Online]. Available: https://indone5ia.wordpress.com.

[8] Zuhri, S. (2018). Inilah Kondisi Kelistrikan di Indonesia Saat Ini. [Online]. Available: https://ekonomi.bisnis.com.

[9] Al-Ali, A.R, Zualkernan, I. A., Rashid, M., Gupta, R., \& Alikarar, M. (2017). A smart home energy management system using IoT and big data analytics approach, Journal of IEEE Transactions on Consumer Electronics, vol. 63, issues 4, no. 4, pp. 426 - 434.

[10] Alamsyah, A. A. (2015). Perancangan dan Penerapan Sistem Kontrol, Journal of Jurnal Mekanikal vol. 6 No. 2, pp. 577-584.

[11] Allen, B., \& Hodge, K. (2017). Saving Time \& Money with Remote Power Management, Access from Minuteman Power Technologies on 3 July 2019, pages 2-7.

[12] Arowana, A. (2016). Electrive, Kontrol Alat Elektronik di Rumah Kini Bisa Lewat Aplikasi. [Online]. Available: https://malangvoice.com. 
[13] Esteve, E., IPnest (2018). New Power Management IP Solution Can Dramatically Increase SoC Energy Efficiency, [Online]. Available: https://www.designreuse.com.

[14] Fitriyani., Kuniadi, D. (2017). Sistem Kendali Jarak Jauh Perangkat Elektronik Rumah Berbasis Cloud Computing, Journal of journals.sttgarut, vol. 14, no. 2, pp. 205- 206.

[15] Han, J., Choi, C.-S., \& Lee, I. (2011). More efficient home energy management system based on ZigBee communication and infrared remote controls, Journal of IEEE Transactions on Consumer Electronics, vol. 57 , issue 1 , pp. $85-89$.

[16] Li, Y., Sun, Z., Han, L., \& Mei, N. (2017). Fuzzy Comprehensive Evaluation Method for Energy Management Systems Based on an Internet of Things, Journal of IEEE Access, vol.5, pp. 21312 - 21322.

[17] Tedyyana, A., \& Kurniati, R. (2016). Membuat Web Server Menggunakan Dinamic Domain. Journal of Jurnal Teknologi Informasi \& Komunikasi Digital Zone, vol.7, no.1, pp. 1-10.

[18] Sun, Y., Song, H., Jara, A. J., \& Bie, R. (2016). Internet of Things and Big Data Analytics for Smart and Connected Communities, Journal of IEEE Access, vol. 4, pp. 766 773.

[19] Susanti, A. (2015). Pakai Smartphone Untuk Ngontrol Alat Elektronik di Rumah, Available: https://news.okezone.com.
[20] Muharam, M., Latif, M., \& Saputra, M. (2018). Sistem Kendali Jarak Jauh Berbasis Web untuk Sistem Rumah Pintar, Journal of Jurnal Nasional Teknik Elektro, vol.7, no.3.pp. 203-208.

[21] Bianchini, R., \& Rajamony, R. (2004). Power and energy management for server systems, Journal of computer, vol. 37, issues 11,pp. $68-76$

[22] Liu, Y., Yang, C., Jiang, L., Xie, S., \& Zhang, Y (2019). Intelligent Edge Computing for IoT-Based Energy Management in Smart Cities, Journal of IEEE Network, vol.33, issue 2, pp. 111-117.

[23] Sinha, A., \& Chandrakasan, A. (2001). Dynamic Power Management in Wireless Sensor Networks, Journal of Wireless Power Management, vol. 18, issue 2, pp. 6274.

[24] Pratomo, B. (2011). Pengembangan sistem kendali dan akuisisi jarak jauh perangkat elektronik berbasis jaringan ip, access from Institut Pertanian Bogor on 3 july 2019, pages $1-51$.

[25] Kurniadi, D., \& Amelia, L. (2018). Sistem Kendali Perangkat Elektronik Rumah Berbasis Android dan Arduino, Journal of Jurnal STT Garut, Vol. 15 No. 2 pp. 1-6.

[26] Hirayama, K., Shibata, H., Inouchi, H., \& Hirata, T. (2000). Next-generation Mobile-access IP Network. Journal of Hitachi Review, vol. 49, no.4, pp. 176-179.

[27] Z, A. (2018). 8 Types of Push Notifications with Great Examples - RubyGarage. [Online]. Available: https://rubygarage.org. 